Article

\title{
Tourism Competitiveness of Rural Areas: Evidence from a Region in Poland
}

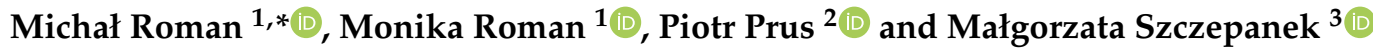 \\ 1 Institute of Economics and Finance, Warsaw University of Life Sciences, 02-787 Warsaw, Poland; \\ monika_roman@sggw.edu.pl \\ 2 Laboratory of Economics and Agribusiness Advisory, Department of Agronomy, Faculty of Agriculture \\ and Biotechnology, UTP University of Science and Technology in Bydgoszcz, 430 Fordońska St., \\ 85-790 Bydgoszcz, Poland; piotr.prus@utp.edu.pl \\ 3 Department of Agronomy, Faculty of Agriculture and Biotechnology, UTP University of Science and \\ Technology in Bydgoszcz, 7 Kaliskiego St., 85-796 Bydgoszcz, Poland; malgorzata.szczepanek@utp.edu.pl \\ * Correspondence: michal_roman@sggw.edu.pl
}

Received: 20 October 2020; Accepted: 19 November 2020; Published: 22 November 2020

\begin{abstract}
The aim of the article is to present the analysis of tourism competitiveness of the rural areas of the Eastern Poland microregion (Podlaskie, Warmińsko-mazurskie, Lubelskie, Świętokrzyskie, Podkarpackie provinces). To group the rural communes in terms of tourism competitiveness, a cluster analysis with Ward's method was applied. To do so, the data provided by the Central Statistical Office (Warsaw) in Poland of 2019 were used. The analyses provided in the article confirm the dependence between the size of the areas of outstanding natural beauty and the region's tourism competitiveness. The results can be applied by the representatives of various institutions and organizations supporting the development of tourism in those areas.
\end{abstract}

Keywords: tourism; competitiveness; rural areas; cluster analysis; Ward's method; Poland

\section{Introduction}

The applicable literature provides many definitions of competitiveness [1]. According to the Organisation for Economic Cooperation and Development (OECD), competitiveness is a tendency and capacity of a given country, region, or enterprise to produce goods, including services satisfying the international market requirements (business going international) under free market conditions, and at the same time, for maintaining and enhancing real personal incomes over a long time, and maintaining long-term development via the technical advancement on permanent, stable, and dynamic grounds [2]. In the report by the World Economic Development of 1994, competitiveness is a tendency and ability of the country, region, or an enterprise to create wealth greater than the competitors and the competitive system on the global market [3], whereas "The World Competitiveness Yearbook" states that international competitiveness should be understood as a tendency and capacity of the country to create the value added and, in that way, to enhance the national wealth by responsible management of the resources and processes, attractiveness and expansiveness and aggressiveness, globally and locally, and to integrate all of these into a homogenous, cohesive, organizational, institutional, and management system in terms of society, economics, culture, ecology, and politics [4].

The essence of competitiveness is one of the most important aspects of regional and local development [5]. The competitiveness of a region is defined as an advantage over other regions, as a derivative of attractiveness of the service offer, addressed to the current and potential users of the region, including the residents, enterprises, investors, and tourists. Its source is state-of-the-art material, as well as the institutional and intellectual infrastructure of the region. It comes from 
the most important strengths of the region, the source of which is found, e.g., in the educational, economic structure, and infrastructure [6]. Enhancing the regional competitiveness is a regular process one can and should affect in a continuous manner [7]. Competitiveness is a factor which conditions the development of regions [8]. The areas compete with one another for development factors and for various groups of end users. A given region welcoming tourists should feature the qualities and attractions that make the tourists choose that specific tourist destination [9].

The aim of this article is to present the analysis of competitiveness of the rural areas of the Eastern Poland microregion in terms of tourism development. To execute the aim, Ward's method was used to facilitate a cluster analysis for the rural communes and combined municipalities with rural communes of five provinces. As part of the primary aim, the authors specified two detailed objectives. The first involved reviewing the term 'tourism competitiveness' by various authors and the second was to determine the spatial variation of rural communes and urban-rural communes in terms of tourism competitiveness. In Poland, communes are broken down into rural communes, urban-rural communes, and municipalities; naturally, this research covers only the first two types.

With the above considerations in mind, it was decided to verify the research hypothesis:

Hypothesis 1 (H1). There is a positive correlation between the level of tourism competitiveness and the size of the areas of outstanding natural beauty in the region.

Respective parts of the article present the rationale for tourism competitiveness and then the spatial analysis of the research part. The introduction in Section 2 is followed by theoretical grounds. That part presents an in-depth literature review on tourism competitiveness. Section 3 discusses materials and methods. Section 4 concerns the results of the cluster analysis and provides a discussion. The last part of the article covers the conclusions.

\section{Literature Review}

Competitiveness can be analyzed applying various criteria, with a different level of measurability. They can include hard criteria (the indicators of general economic growth, indicators informing of the structural changes and changes in effectiveness, and indicators informing of the involvement in the international economic exchange) and soft criteria (more difficult to measure), especially education and human capital, creativity, and entrepreneurship. The hard criteria can be analyzed in a short-time cycle, whereas the soft criteria are related to longer cycles. The more economically developed the region, the more its development and competitiveness depend on the soft criteria [10].

Competitiveness can be measured with specialization, especially disclosed comparative benefits. On the other hand, competitiveness has been derived from a competitive 'fight', competitive advantage and position. In the applicable literature, one can find three groups of competitiveness measures, namely foreign trade measures, indicators of microeconomic effectiveness, and subjective measures [11].

In the report, "The World Competitiveness Yearbook," to assess the macroeconomic competitiveness of domestic economies, including regions, 288 different kinds of criteria are broken down into eight groups (a macroeconomic approach) and applied [4].

The first group includes the directions of change and the condition of the country's economy. The economy or the region can be analyzed in a real or nominal (financial) domain. Currently, one can associate 'economic organism' with a nominal domain in terms of financial market, with the money market (money market instruments), securities (ownership instruments), and lending market (saving and investment instruments). The financial market concerns, for example, broking to leverage the capital and its transfer and using it as a short- and long-term credit. With that in mind, to evaluate the macroeconomic competitiveness of the economy, including the region, one considers the level, dynamics, and tendencies of the real changes in gross domestic product (GDP) per capita-the level and dynamics of real wage, the level of inflation; the banking system condition - the current account, the level, and the dynamics; the directions of changes in investments-domestic savings and 
consumption; tendencies of change in the development of basic economic sectors-the cost of living and economic restructuring assessment; and the directions of change in the relationship between enterprises and the state, the condition of the natural environment, the amount of raw materials, and natural resources consumed in the production process in the reporting period. The lower the cost of the increase in GDP from the point of view of the resources consumed per capita, or changes in the condition of the natural environment, the higher the competitiveness. Besides, the factors affecting the economy and the region are the location attractiveness (which facilitates attracting the investors), the raw material base, the supply and demand market accessibility, the availability of qualified workforce, the accessibility to other economic areas to execute the expansion strategy, and the operation of special economic zones. As an example of enhancing the competitiveness of the regions, the existence of the scientific research and implementation facilities for enterprise is important, i.e., technology parks and business incubators, as well as the natural environment conditions factor, namely the condition of the human natural environment (water, air, soil, landscape diversity, climate conditions, and level of landscape planning) [4].

By applying various protection forms and measures, the second group covers the tendencies of changes in terms of going international and the condition of international economic relations, especially participation in international trade, the exports per capita, a change in the trade balance, the export and import structure, foreign exchange rate change tendencies, changes in foreign investments, and assessment of the tendency for the economy to expand [4].

Another group stands for the assessment of changes in the involvement of the state in economic activity (the quality of the management of the economy and the region-the level of competencies, responsibilities and politicizing the economy, the level and the tendencies to changes in the country's debt; the budget deficit and the condition of public finance and its structure-public debt and public debt servicing costs, possibilities of capital inflow, a favorable taxation system, changes in the government expenditure level, the fiscal policy towards enterprises and physical persons, and the level of the involvement of the state in the economic life; and price control-subsidies and regulating the job market, assessment of personal safety, safety of property and ownership), political risk, justice, and corruption and crime) [4].

The successive three groups of competitiveness assessment criteria concern the business environment and efficiency [4]:

- The financial part and financial system efficiency (public and private sector savings, capital assessment and capital accessibility, originating from domestic and foreign savings, credits, credit terms and conditions, capital market development tendencies and dynamics, banking sector effectiveness, central bank policy, legal regulations, credit card transparency, and popularization);

- The level and directions of economic infrastructure development (saturation with infrastructure, especially the transport infrastructure-condition and directions of development of road transport, roads, rail transport, air transport, waterborne transport, power grid, urbanization, health insurance system; the level and directions of development of the technical infrastructuretelecommunications, computerization, popularizing the Internet, social and institutional infrastructure, energy self-sufficiency assessment; and the level and direction of changes in natural environment protection);

- The level and directions of science and technology development (the participation of the degree-holders in the total number employed, research and development $(R+D)$ inputs, the amount of $\mathrm{R}+\mathrm{D}$ expenditure per capita, $\mathrm{R}+\mathrm{D}$ management level, and the intellectual rights system; the number of the patent rights conferred for every 1000 residents, purchasing and trading in technologies, the level of creativity and entrepreneurship of the domestic and the region's economy, and the participation in the manufacture of high-tech goods);

- Changes in the level and directions of workforce productivity and equipment effectiveness, a total factor productivity, especially workforce, the level and dynamics of workforce productiveness, 
labor efficiency, management effectiveness and efficiency, and the condition of employment relations and corporate culture;

- The tendencies of job market development—employment, unemployment, and human capital development, measured with the development of education; tendency of changes in the quality of life; and changes in the system of values and social relations.

The level of a region's tourism competitiveness is affected by the factors presented in Table 1.

Table 1. Factors affecting a region's tourism competitiveness.

\begin{tabular}{|c|c|}
\hline Factors & Specification \\
\hline Economic & $\begin{array}{l}\text { - } \quad \text { production factor resources, } \\
\text { - } \quad \text { rate of inflation, } \\
\text { - } \quad \text { levemployment rate, } \\
\text { - } \quad \text { state of infrastructure (well-developed local and regional } \\
\text { infrastructure ensuring easiness in running business, a network of } \\
\text { roads with a good road surface condition, utility infrastructure, and } \\
\text { good transport accessibility), } \\
\text { functional infrastructure for the tourist reception area (tourist trails), } \\
\text { innovations. }\end{array}$ \\
\hline Social & $\begin{array}{l}\text { - level of qualifications and the level of education background of } \\
\text { the residents, } \\
\text { - } \quad \text { availability of qualified human resources, } \\
\text { availability and potential of educational, cultural, and recreational } \\
\text { institutions, and a high R+D potential, } \\
\text { - high R+D sector, education, training inputs. }\end{array}$ \\
\hline Legal & $\begin{array}{l}\text { - legal instruments in a form of acts, directives and regulations of public } \\
\text { authorities, the stability of those provisions, tax relief application, tax } \\
\text { exemptions for new investors, and a simplified procedure for starting } \\
\text { and running a business. }\end{array}$ \\
\hline Geographic and topographic & $\begin{array}{l}\text { - } \quad \text { high quality of the natural environment, } \\
\text { - } \quad \text { location benefits, } \\
\text { natural resources related to the possibility of running a } \\
\text { tourism business. }\end{array}$ \\
\hline
\end{tabular}

Research and development (R+D) Source: [12].

The factors can be divided into two categories: the ones necessary to maintain a capacity to compete and the ones that create a competitive advantage resulting from the appearance of additional qualities that definitely enhance the acquisition of investors. In each region of Poland, one can find all the factors; however their potential and quality differ, which frequently becomes an immediate reason for the disproportions between the levels of development of respective regions. In the European Union, Poland is increasingly seen as a region attractive for tourists [13].

The increase in the region competitiveness is mainly due to tourism. A development of tourism in the region can enhance not only the infrastructure, due to the needs resulting from tourists' travels (e.g., historic sites and beach management), but also a development of infrastructure satisfying the needs of both the residents and the tourists (e.g., banking and commercial services, and the water and sewage system) [14].

The development of tourism and an immediately related tourism flow activate the local economy through the inflow of capital, the development of small- and medium-sized enterprises, and by creating new jobs. In addition, the local enterprises can generate higher turnovers from sales, the income of the local residents increase, and the budget collects a greater amount of taxes [15]. The importance of tourism is even greater as it also creates an additional business in other sectors (e.g., the construction sector, industry, agriculture). Any change in the demand for tourism services affects the suppliers of that tourism sector, then their subsuppliers, etc. [16] 
Table 2 presents a list of publications on tourism competitiveness. The publications were added from a literature review.

Table 2. List of publications on tourism competitiveness (according to the date of publication).

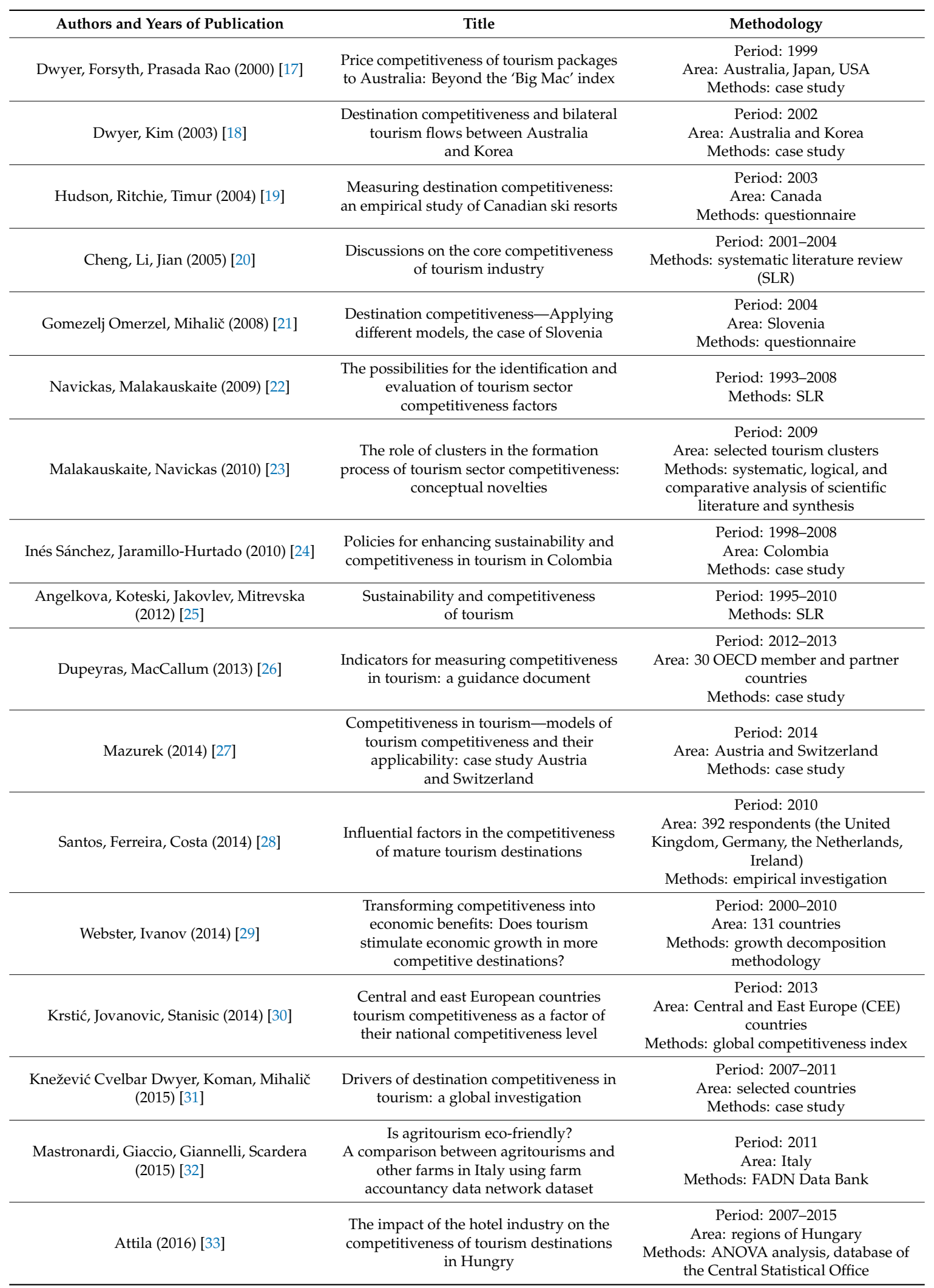


Table 2. Cont.

\begin{tabular}{|c|c|c|}
\hline Authors and Years of Publication & Title & Methodology \\
\hline Andrades, Dimanche (2017) [34] & $\begin{array}{c}\text { Destination competitiveness and tourism } \\
\text { development in Russia: Issues } \\
\text { and challenges }\end{array}$ & $\begin{array}{c}\text { Period: } 1995-2014 \\
\text { Area: Russia } \\
\text { Methods: UNWTO data, Travel and } \\
\text { Tourism Competitiveness Report }\end{array}$ \\
\hline Liu, Yen, Tsai, Lo (2017) [35] & $\begin{array}{l}\text { A conceptual framework for agri-food } \\
\text { tourism as an eco-innovation strategy in } \\
\text { small farms }\end{array}$ & $\begin{array}{c}\text { Period: } 2017 \\
\text { Area: Taiwan } \\
\text { Methods: case study }\end{array}$ \\
\hline
\end{tabular}

Systematic literature review (SLR), Organisation for Economic Cooperation and Development (OECD), Central and East Europe (CEE), FADN (Farm Accountancy Data Network), World Tourism Organization A Union Nations Specialized Agency (UNWTO) Source: [17-36].

The scientific publications presented in Table 2 show that the papers focus on the use of databases or other methods to develop the tools demonstrating a variety of competitiveness in tourism. The authors use different variables to show the problem complexity. Some authors determine the tourism competitiveness specialization with a comparative analysis and taxonomic methods, and some of them have performed applicable survey studies.

While developing the literature review, one can note that many authors have made a case study to demonstrate the tourism competitiveness. In their article, Dwyer et al. [17] present a price competitiveness for package tour destinations. In their opinion, a tourism product is a very complex product made up of various components depending on the tourists' spending patterns. There is no balanced tourism product offered in various countries, as the nature of the product is adapted to the market of origin, the level of expenditure, and the duration of the visit. The authors' method to develop price competitiveness can be used to develop the measures of price competitiveness of various tour packages. The key objective of the authors has been to determine the essence of the preferred approach to the measurement of price competitiveness, as well as to develop the indicators of price competitiveness for package tours to Australia from Japan and the United States. It was also essential to specify the areas for further research of price competitiveness for tourism organized all across the world.

Dwyer and Kim [18], in their case study, have proven that a further development of tourism sector capacity in the region of Asia and the Pacific will depend mainly on its capacity for a further prosperous operation on an increasingly competitive international market. Recognizing that fact has triggered a joint project of the Department of Science and the Industrial Resources and the National Centre for Tourism in Sydney (Australia) and the Korean Ministry of Culture and Tourism in Seul (Korea), in cooperation with the Korean Institute of Tourism in Seul (Korea).

Sánchez and Jaramillo-Hurtado [24] present a review of tourism policy in Colombia and accounted for the measures taken to enhance the competitiveness and the economic input of the tourism sector. The article provides a historical perspective of tourism in Colombia in 1998-2008 and accounts for the political initiatives designed to speed the development of tourism and to enhance the effect of sustainable ecotourism as a strategy to promote the protection of rainforests in Colombia's Amazonia. The article discusses the success of Colombia, where tourism has been developing and is expected to grow at a faster rate than expected for global tourism.

The essence of tourism competitiveness has been demonstrated by Dupeyras and MacCallum [26] in the document issued by the OECD. In their opinion, mature tourism economies must regain competitiveness as a new source of growth. Active policies require a good understanding of competitiveness determinants. Those measurement frameworks cover a short list of the key and additional indicators to be used by the governments for the analysis of tourism competitiveness and they inform of the development of tourism policy. Countries should consider using the frameworks as a tool kit and a guide.

A case study was also used by Mazurek [27]. In her opinion, the concept of competitiveness has been adapted to tourism from various disciplines, also covering management and marketing. 
It also accounts for the concept of competitiveness of management, marketing, and leadership being important for success. The case study involved Austria and Switzerland.

The last quoted authors presenting a case study are Dwyer et al. [31]. In their opinion, the debates on competitiveness and productivity are practically indispensable in terms of tourism. In their article, they assume a productivity-related measure: the total contribution of tourism to GDP per employee to investigate the destination competitiveness. In their opinion, the comprehensive results based on the destination competitiveness model are developed with an analysis of tourism-specific and general economic competitiveness factors. They are presented with six destination competitiveness factors, measured with 55 indicators for 139 destinations in 2007-2011. Their research results show that the tourism-specific factors, especially tourism and destination management, are the key factors stimulating competitiveness in the developing countries, while the destination competitiveness in developed countries depends on the tourism-specific center management as well as on broader economic factors, especially general infrastructure, macroenvironment, and business environment.

A case study was also applied by Liu et al. [35], who present a case study made on a family farm in the territory of the Paiwan, the indigenous people in the Central Mountain Range in Taiwan. The case study stresses how a good farmer is essential for attracting other indigenous farmers to get involved in sustainable practices to help maintain the cultural, social, and environmental systems, and, at the same time, present agrifood tourism as a brand identity.

The research performed by Hudson et al. [19] presents a model developed for tourism destination competitiveness adapted for skiing destinations, and then operational measures were developed for each model element to ensure the destination competitiveness index for skiing destinations in Canada. The authors investigated 13 skiing areas with a detailed stakeholders' questionnaire. Their results highlight the strengths and weaknesses of each destination and show that the opinions of the key stakeholders can be very useful for indicative targets. The research provides the grounds for developing a measurement model for comprehensive and normalized global tourist resort competitiveness. The model can be a useful tool to plan and to develop resorts operating in highly competitive markets.

According to Gomezelj Omerzel and Mihalič [21], the competitiveness of a tourist country is important especially when countries aim for higher market shares. Tourism managers should identify and investigate the competitive advantages and analyze the competitive position of the destination. Their study focuses on the competitive destination model by De Keyser-Vanhove, applied in Slovenia in 1998. The research results show that Slovenia is more competitive in terms of its natural and cultural resources but less competitive in terms of tourism management.

Focusing on tourism competitiveness, Santos et al. [28] performed their research in 2010 at the international airport in Faro (Portugal), which involved 392 respondents. In their opinion, the factors that can have a negative effect on the results of mature tourism destinations can be divided into four areas. The first area concerns the destination infrastructure degradation. The second factor is related to destination management, a lack of a joint strategic vision among the parties interested. The third area is related to a loss of economic viability of destinations. The fourth covers the effect of tourism development over years in a given area, especially the social, environmental, and cultural effects. Their results of empirical studies demonstrate that a lack of environmental problems, a lack of excessive structural development, and maintenance of authenticity are considered by the tourist to be more important for the tourism destinations competitiveness than the usual factors considered more important, especially the prices and quality of accommodation.

In their article, Malakauskaite and Navickas [23] analyzed clusters and their effect on tourism sector competitiveness. In their opinion, tourism sector competitiveness can be described as an effect of the synergy between the natural and anthropogenic tourism destination attractiveness factors. In their article, they demonstrate the role of clusters for tourism sector competitiveness development. The research carried out by the authors shows that tourism enterprises representing the cluster enjoy better access to complementary services. They can also cooperate with the government and academic institutions, which frequently provide the assistance to stimulate the tourism sector development. 
Besides, local universities and higher education providers educate potential tourism sector managers and they can adapt their study programs to meet the needs of the enterprises.

In the article by Andrades and Dimanche [34], Russia is presented as a destination for tourists. The authors compared Russia to the leading tourist destinations with transition economies. They identified some weaknesses and problems that Russia should consider in order to become more competitive. In their opinion, Russia is a country with huge tourism potential not yet used completely. Their research is a result of a three-year project with partners from Europe and Russia participating.

Cheng et al. [20] analyzed the contents of articles to draw conclusions on tourism competitiveness. The characteristic resources account for the competitive advantage of the region, and the key to tourism competitiveness are the internal resources. In their opinion, one can consider competitiveness of tourist attractions as the basic competition of the tourism industry. The tourism product is a form of tourism industry. Due to the level of competitiveness, the tourism product is finally represented through the sale of tourism products. Tourism is one of the sectors requiring high-quality services. The quality of the services affects the tourism competitiveness. The key to industrial competition is developing a comparative advantage; hence the service as an important innovation in tourism development. Besides, the essential competitive development of the tourism sector is affected by the government policy-its management and corporate strategy, etc.

In their article, Navickas and Malakauskaite [22] made a vast review of literature from 1993-2008. In their opinion, the competitiveness of destinations for tourists is increasingly important for the countries that intend to control a considerable part of the fast-developing tourism market. It is of special importance for countries dependent on tourism which, to a large extent, depends on the situation in tourism and tourist industry. The competitiveness of the tourism sector covers many factors, especially the natural environment (geographic location, climate, landscapes, etc.), artificial environment (tourism infrastructure, transport, recreational, and entertainment services supply, including retail stores, hotel chains, villa rental), and market globalization. According to the authors, the identification and the assessment of tourism competitiveness factors is often a frequent research problem in many scientific studies and articles on tourism economics.

In their article, Angelkova et al. [25] reviewed literature from 1995 to 2010. In their opinion, tourism is an activity that can have a high impact on sustainable development. The sustainable development of tourism requires extensive cooperation between tourism enterprises, tourist facilities, and the national, regional, and local authorities, in order to face a greater group of challenges and to maintain competitiveness concurrently. The possibility of sustainable development of tourism and maintaining its competitiveness is considerably affected by the quality of the environment, maintaining an attractive natural and cultural heritage, and by other values, goods, and resources.

A systematic literature review was used by Barbieri [36]. The author recapitulates essential descriptive, ontological, and epistemological progress of research of agritourism from its origins. She presents the future of the agritourism space and research. In her opinion, the agritourism studies performed so far have made considerable descriptive, ontological, and epistemological advancements to preserve the scientific importance of agritourism as a subject of study. Future research efforts should concern where agritourism, as a farm diversification strategy, ends on the educational-recreational continuum and how the agritourism space can enhance negotiating the growing social dissonances resulting from a gap between rural and urban areas.

In their article, Webster and Ivanov [29] demonstrate the impact of destination competitiveness on the share of tourism in economic growth, applying the cross-section of 131 countries for 2000-2010. Destination competitiveness was measured with the indicator of travel and tourism of the World Economic Forum, and the share of tourism in economic growth was determined using the growth decomposition method. Their results show that destination competitiveness has no significant effect on the share of tourism in economic growth.

Krstić et al. [30], on the other hand, presented the effect of travel and tourism competitiveness on the global-level competitiveness of the countries of Central and Eastern Europe. The objective of 
their article was to identify the correlation between the level of travel and tourism competitiveness accomplished (measured with the travel and tourism competitiveness index, TTCI) and the national level of competitiveness on the global list (measured with the global competitiveness index, GCI) in the countries of Central and Eastern Europe. Their research results demonstrate that there is a strong correlation between GCI and TTCI. The results of the research point to the possible directions for the decision-makers in terms of the development in the countries of Central and Eastern Europe.

Mastronardi et al. [32] presented the results of research on the environmental effectiveness of Italian agritourism farms, as compared with the farms without agritourism. The authors used the most common sustainable development indicators. They presented how Italian agritourism tends to develop more environment-friendly agricultural methods, enhancing biodiversity, landscape, and natural resources. The empirical analysis is based on a dataset by the Italian Farm Accountancy Data Network (FADN).

In the article, [33] applied ANOVA and the database from 2007-2015. Attila [33] presented the key tourists' destinations in Hungary in terms of the microregion, which justifies the importance and the share of the hotels and bed and breakfasts (B\&Bs) in the competitiveness and the tourism destination success. His article focuses on a complex aspect from the perspective of the hotel sector. The research facilitated defining three groups of microregion destinations in Hungary. In the first group of the best developed and the most competitive tourism destinations, the hotel sector is essential. In those regions it has a significant effect not only on tourism competitiveness but also on the general development of the regions. In the second group, which can be still referred to as the tourism destination, tourism and the hotel sector are crucial; however, only tourism competitiveness can be considered good, whereas the impact of tourism on the general development of the region can be less effectively assessed. In the third group, only less considerably can one experience the effects of tourism and the hotel sector. Most of those regions are no longer considered attractive tourism destinations.

In this paper, tourism competitiveness was determined at the level of the region. The competitiveness of the regions can be differently understood; however, in the economic categories, competitiveness is a capacity for being successful in the economy of competition. A varied offer of each region, frequently very similar to one another, forces the authorities of respective regions to compete for the entities which could use it. Competition between the regions can involve attracting private investors (also tourists) and acquiring subsidies and other forms of support from the state budget or the EU assistance [37]. The local authorities, based on their resources and needs, join the competition in various domains. The group includes tourism competitiveness or competitiveness in terms of tourism development.

\section{Materials and Methods}

Tourism competitiveness of rural areas was verified with cluster analysis. Cluster analysis is a set of methods of multivariate statistical analysis to identify the homogenous subsets of objects of the population studied. The measures of similarities or differences are based on the distances between individuals [38]. Distance d (Object $i\left(\mathrm{O}_{\mathrm{i}}\right)$, Object $\left.\mathrm{j}\left(\mathrm{O}_{\mathrm{j}}\right)\right)$ is a function of dissimilarity of a pair of objects $(\mathrm{Oi}, \mathrm{Oj})$ since the greater the distance between two objects, the more dissimilar they are to each other. In clustering, the objects found close to each other, and at the same time being far from the others, are combined, creating another cluster. This paper applied the Euclidean distance. All the variables were exposed to standardization. For object clustering, Ward's method was selected [39]. To select the number of classes, the cubic clustering criterion (CCC) and Pseudo F were applied [40,41]. All the calculations were made using Statistical Analysis System (SAS) 9.4 software (Cary in United States).

To verify the objective, the authors based the analysis on secondary data collected by the Central Statistical Office [42]. For the analysis, the latest data available were selected, which are the data for 2019. For a reason, the rural areas from the region in Eastern Poland were also selected, which covers five provinces: Warmińsko-mazurskie, Podlaskie, Lubelskie, Świętokrzyskie and Podkarpackie. The macroregion of Eastern Poland is a peripheral and border area, far from the main economic centers, with a low investment rate and an inconsiderable inflow of foreign investments, for example. It is 
mostly due to a low level of economic and social infrastructure and insufficient activity of the provinces in terms of attracting investors.

To measure the tourism competitiveness of the regions, the variables as the indicators referring to tourists and economic enterprises (providing accommodation and food services) were applied [43-45]:

$T M-$ share in the tourism market

$$
T M=\frac{\text { number of tourists in the region }}{\text { number of tourists in the country }}
$$

SI-Schneider's index

$$
S I=\frac{\text { number of overnight stays }}{\text { population }} \times 100
$$

CHI-Charvat's index

$$
\text { CHI }=\frac{\text { number of the nights spent }}{\text { population }} \times 100
$$

TD—tourism density

$$
T D=\frac{\text { number of toursits }}{\text { area in } \mathrm{km}^{2}}
$$

NEEA - number of economic enterprises (providing accommodation and food services) for every $10 \mathrm{~km}^{2}$;

NEER—number of economic enterprises (providing accommodation and food services) for every 1000 residents;

EETN-share of tourism-related economic enterprises in the total number of private economic enterprises.

The analysis of the tourists was performed for the counties (87 objects), whereas the analysis of economic enterprises was for the communes ( 627 objects). The selection was due to data availability. One must note that, besides the content-wise criterion, the selection of the variables also resulted from a low correlation between the variables (the value of the correlation coefficient below 0.8 ).

The descriptive statistics of variables are provided in Table 3.

Table 3. Descriptive statistics of variables.

\begin{tabular}{ccccccc}
\hline Variable & Mean & Median & Minimum & Maximum & $\begin{array}{c}\text { Standard } \\
\text { Deviation }\end{array}$ & $\begin{array}{c}\text { Coefficient of } \\
\text { Variation (CV) }\end{array}$ \\
\hline TM & 0.12 & 0.06 & 0.01 & 0.82 & 0.14 & $123 \%$ \\
SI & 69.30 & 34.05 & 3.69 & 769.74 & 122.24 & $176 \%$ \\
CHI & 207.44 & 69.35 & 4.39 & 3300.30 & 447.01 & $215 \%$ \\
TD & 38.35 & 20.41 & 1.53 & 275.45 & 48.85 & $127 \%$ \\
NEEA & 1.13 & 0.69 & 0.03 & 20.42 & 1.56 & $137 \%$ \\
NEER & 2.10 & 1.41 & 0.15 & 61.95 & 4.07 & $194 \%$ \\
EETN & 3.02 & 2.33 & 0.29 & 40.44 & 3.29 & $109 \%$ \\
\hline
\end{tabular}

Share in the tourism market (TM), Schneider's index (SI), Charvat's index (CHI), tourism density (TD), number of economic enterprises (providing accommodation and food services) for every $10 \mathrm{~km}^{2}(\mathrm{NEEA})$, number of economic enterprises (providing accommodation and food services) for every 1000 residents (NEER), share of tourism-related economic enterprises in the total number of private economic enterprises (EETN).

The research hypothesis was verified with the analysis of correlation and the logit model. The dependent variable was the level of tourism competitiveness of the regions determined from a cluster analysis, while the independent variable was the size of the areas protected by law in a given region. 


\section{Result and Discussion}

\subsection{Estimate of Competitiveness Based on the Tourist-Related Indicators}

The first step involved an attempt at estimating the competitiveness of the regions with the use of tourist-related data. To do so, grouping the regions included the variables: TM, SI, CHI, TD. Figure 1 presents the results of county grouping in terms of the level of tourist-related tourism competitiveness. The analysis excluded the cities acting as municipalities.

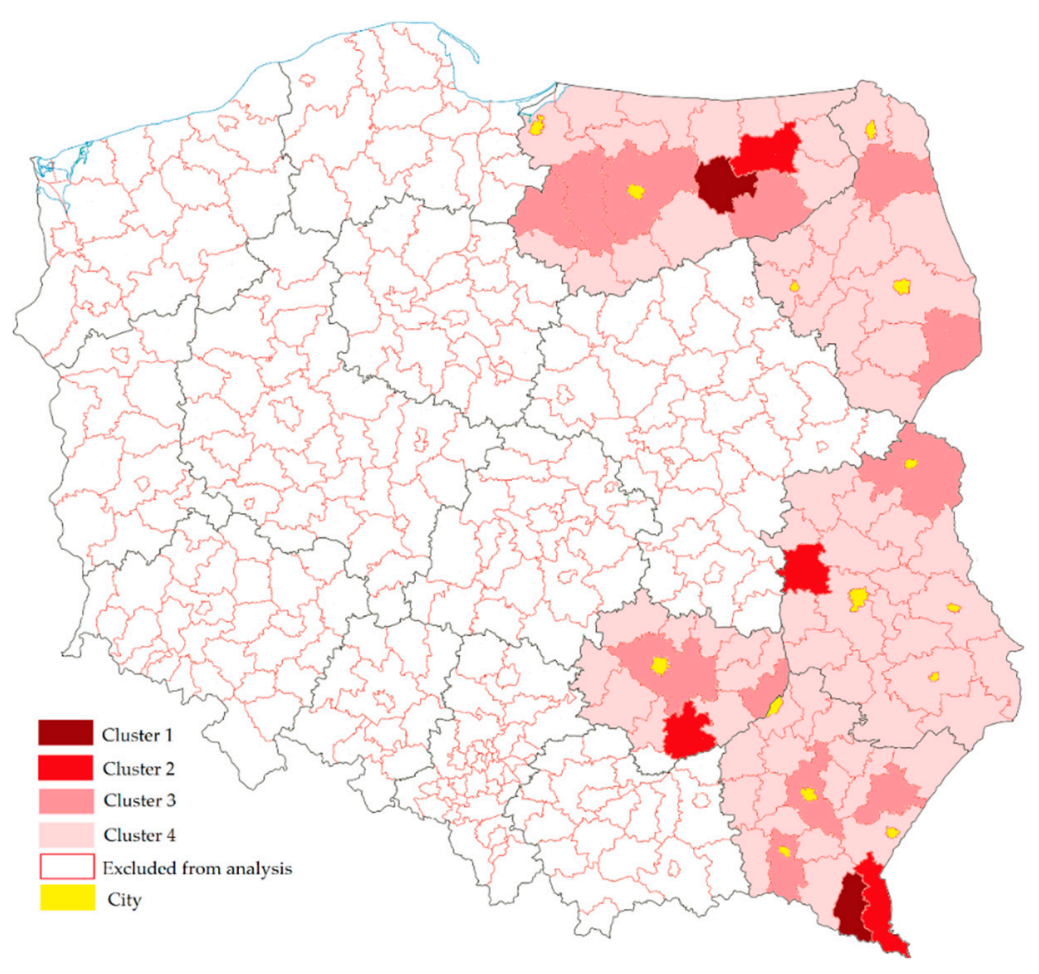

Figure 1. Counties grouping based on the cluster analysis. Source: this research.

The most competitive are the regions of Cluster 1 . The group included two counties: Leski and Mragowski. These regions feature the highest mean values of all the variables (Table 4). The area that is well-developed in terms of tourism is considered the one for which Schneider's index scores at least $500[46,47]$, and it is the case for the two regions. Charvat's index also scored very high in that group, on average, 2439.93. 
Table 4. Descriptive characteristics of the clusters.

\begin{tabular}{|c|c|c|c|c|c|c|}
\hline \multicolumn{2}{|c|}{ Cluster Name } & Descriptive Statistics & TM & SI & $\mathrm{CHI}$ & TD \\
\hline \multirow{16}{*}{ Ward's method } & Cluster 1 & \multirow{4}{*}{ Mean } & 0.70 & 679.62 & 2439.93 & 259.59 \\
\hline & Cluster 2 & & 0.43 & 305.8 & 1014.56 & 150.28 \\
\hline & Cluster 3 & & 0.24 & 91.58 & 246.28 & 56.43 \\
\hline & Cluster 4 & & 0.06 & 31.85 & 81.91 & 21.32 \\
\hline & Cluster 1 & \multirow{4}{*}{ Minimum } & 0.57 & 589.5 & 1579.55 & 243.74 \\
\hline & Cluster 2 & & 0.34 & 168.56 & 622.63 & 112.71 \\
\hline & Cluster 3 & & 0.15 & 51.51 & 96.38 & 36.37 \\
\hline & Cluster 4 & & 0.01 & 3.69 & 4.39 & 1.53 \\
\hline & Cluster 1 & \multirow{4}{*}{ Maximum } & 0.82 & 769.74 & 3300.30 & 275.45 \\
\hline & Cluster 2 & & 0.59 & 592.57 & 1642.61 & 223.57 \\
\hline & Cluster 3 & & 0.37 & 145.02 & 510.75 & 81.78 \\
\hline & Cluster 4 & & 0.17 & 87.58 & 593.98 & 76.83 \\
\hline & Cluster 1 & \multirow{4}{*}{ Standard deviation } & 0.18 & 127.45 & 860.38 & 22.42 \\
\hline & Cluster 2 & & 0.11 & 197.13 & 422.00 & 50.14 \\
\hline & Cluster 3 & & 0.07 & 35.31 & 134.98 & 16.45 \\
\hline & Cluster 4 & & 0.04 & 20.84 & 92.58 & 15.95 \\
\hline
\end{tabular}

Share in the tourism market (TM), Schneider's index (SI), Charvat's index (CHI), tourism density (TD).

The regions that must be considered as the second highly competitive ones in terms of tourism are found in Cluster 2. The cluster covers four counties: Bieszczadzki, Buski, Giżycki, and Puławski. In those regions, the average value of Schneider's and Charvat's indices was 305.8 and 1014.56, respectively. Besides, the average tourism density was 150.28 people $/ \mathrm{km}^{2}$.

The average level of tourism competitiveness was recorded for the objects in Cluster 3. The group included as many as 12 counties: Augustowski, Bialski, Hajnowski, Iławski, Jarosławski, Kielecki, Krośnieński, Olsztyński, Ostródzki, Piski, Rzeszowski, and Sandomierski. For those objects, Schneider's index was, on average, 91.58, whereas Charvat's index was 246.28.

The last cluster included the other counties of Eastern Poland, with a low level of tourism competitiveness (Cluster 4). In those regions, the average level of all the variables was lowest.

\subsection{Assessment of Competitiveness Based on the Economic-Enterprises-Related Indicators}

A further step involved the analysis of tourism competitiveness of the regions based on the economic-enterprises-related data. For this purpose, the variables NEEA, NEER, and EETN were applied. In addition, due to data availability, the analysis was performed at a more detailed level, at the level of communes, which facilitated providing more accurate results. The study was carried out for the rural communes and urban-rural communes, excluding the municipalities. The results of commune grouping with the use of cluster analysis are presented in Figure 2.

The most competitive are the communes in Cluster 1. The cluster covers four communes (three rural communes and once urban-rural commune): Białowieża, Cisna, Kazimierz Dolny, and Solina. In the communes, the average number of tourism enterprises was 11.22 for every $10 \mathrm{~km}^{2}$, and the average share of tourism enterprises in the total number of enterprises accounted for, on average, $32.63 \%$ (Table 5).

A high level of tourism competitiveness is recorded for the communes in Cluster 2. The group covers 27 communes (19 rural communes and 8 urban-rural communes). In those communes, the average number of tourism enterprises was only 1.81 for every $10 \mathrm{~km}^{2}$; however, the average share of tourism enterprises in the total number of enterprises accounted for, on average, $10.54 \%$.

The communes in Cluster 3 featured the average level of tourism competitiveness in terms of economic objects. The cluster covered 39 communes ( 21 rural communes and 18 urban-rural communes). In those communes, the average number of tourism enterprises was 4.33 for every $10 \mathrm{~km}^{2}$; however, the share of tourism enterprises in the total number of enterprises accounted for, on average, $3.37 \%$. 


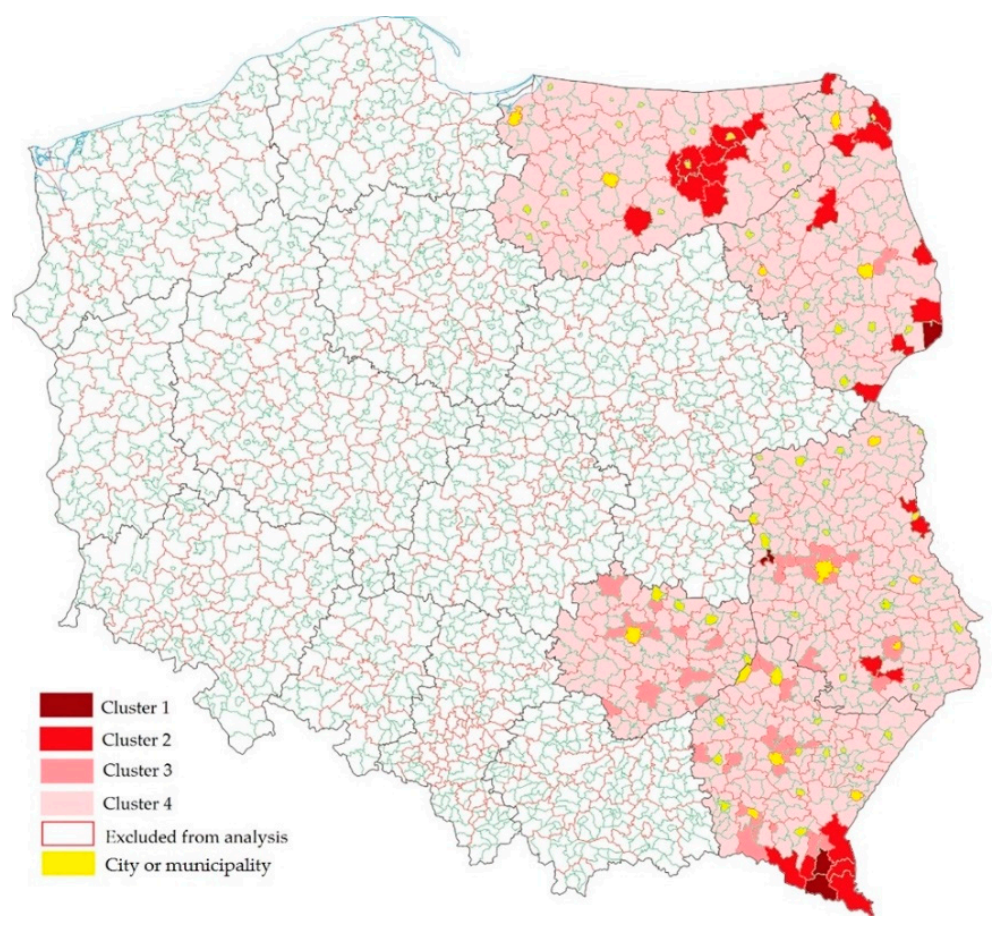

Figure 2. Commune grouping based on the cluster analysis. Source: this research.

Table 5. Descriptive characteristics of the clusters.

\begin{tabular}{|c|c|c|c|c|c|}
\hline \multicolumn{2}{|c|}{ Cluster Name } & Descriptive Statistics & NEEA & NEER & EETN \\
\hline \multirow{16}{*}{ Ward's method } & Cluster 1 & \multirow{4}{*}{ Mean } & 11.22 & 42.72 & 32.63 \\
\hline & Cluster 2 & & 1.81 & 8.36 & 10.54 \\
\hline & Cluster 3 & & 4.33 & 2.94 & 3.37 \\
\hline & Cluster 4 & & 0.80 & 1.45 & 2.42 \\
\hline & Cluster 1 & \multirow{4}{*}{ Minimum } & 3.10 & 22.14 & 19.47 \\
\hline & Cluster 2 & & 0.35 & 3.04 & 6.52 \\
\hline & Cluster 3 & & 2.91 & 1.47 & 1.53 \\
\hline & Cluster 4 & & 0.03 & 0.15 & 0.29 \\
\hline & Cluster 1 & \multirow{4}{*}{ Maximum } & 20.42 & 61.95 & 40.44 \\
\hline & Cluster 2 & & 6.45 & 26.21 & 19.43 \\
\hline & Cluster 3 & & 10.22 & 7.24 & 7.05 \\
\hline & Cluster 4 & & 2.81 & 5.03 & 7.77 \\
\hline & Cluster 1 & \multirow{4}{*}{ Standard deviation } & 9.19 & 20.19 & 9.76 \\
\hline & Cluster 2 & & 1.56 & 5.34 & 3.11 \\
\hline & Cluster 3 & & 1.67 & 1.44 & 1.56 \\
\hline & Cluster 4 & & 0.63 & 0.85 & 1.28 \\
\hline
\end{tabular}

number of economic enterprises (providing accommodation and food services) for every $10 \mathrm{~km}^{2}$ (NEEA), number of economic enterprises (providing accommodation and food services) for every 1000 residents (NEER), share of tourism-related economic enterprises in the total number of private economic enterprises (EETN).

Cluster 4 included the other communes with a level of tourism competitiveness that must be considered very low. In those communes, the average number of tourism enterprises was only 0.80 for every $10 \mathrm{~km}^{2}$, and the average share of tourism enterprises in the total number of enterprises accounted for only $2.42 \%$.

\subsection{Tourism Competitiveness and Natural Qualities}

The next step involved the analysis of the dependence between the size of the areas of outstanding natural beauty, the green areas, woodland, and the variables TM, SI, CHI, TD, and NEEA used for the 
analysis of tourism competitiveness of the regions. To do so, the Pearson correlation coefficient and regression analysis were used. The results of the analysis are given in Table 6.

Table 6. Results of Pearson correlation and regression.

\begin{tabular}{|c|c|c|c|c|}
\hline \multirow{2}{*}{$\begin{array}{c}\text { Specification } \\
\text { Variables }\end{array}$} & \multicolumn{2}{|c|}{ Protected Areas Size } & \multirow{2}{*}{$\begin{array}{c}\text { Woodland Area } \\
\begin{array}{c}\text { Coefficient of } \\
\text { correlation }\end{array}\end{array}$} & \multirow{2}{*}{$\begin{array}{c}\text { Parks and Green } \\
\text { Areas Size } \\
\begin{array}{c}\text { Coefficient of } \\
\text { correlation }\end{array}\end{array}$} \\
\hline & $\begin{array}{l}\text { Coefficient of } \\
\text { correlation }\end{array}$ & $\begin{array}{l}\text { Function and selected results } \\
\text { of regression }\end{array}$ & & \\
\hline $\mathrm{TM}$ & $0.47^{*}$ & $\begin{array}{c}y=0.21 \times+0.03\left(R^{2}=0.14\right. \\
\left.F=13.37^{*}\right)\end{array}$ & 0.05 & 0.20 \\
\hline SI & $0.36^{*}$ & $\begin{array}{c}y=212.64 \times-17.17\left(R^{2}=0.20,\right. \\
\left.F=20.49^{*}\right)\end{array}$ & 0.09 & -0.06 \\
\hline $\mathrm{CHI}$ & $0.35^{*}$ & $\begin{array}{c}y=837.43 \times-133.11 \\
\left(R^{2}=0.23, F=24.76^{*}\right)\end{array}$ & 0.18 & -0.05 \\
\hline $\mathrm{TD}$ & $0.25 *$ & $\begin{array}{c}y=71.10 \times+9.44\left(R^{2}=0.14\right. \\
\left.F=13.33^{*}\right)\end{array}$ & 0.07 & 0.21 \\
\hline NEEA & 0.03 & $\begin{array}{c}\mathrm{y}=1.14 \times+0.78\left(\mathrm{R}^{2}=0.11\right. \\
\left.\mathrm{F}=10.10^{*}\right)\end{array}$ & 0.13 & $0.37^{*}$ \\
\hline $\begin{array}{l}\text { Region's tourism } \\
\text { competitiveness }\end{array}$ & 0.43 * & $\begin{array}{l}\text { Polynomial ordered logit } \\
\text { model (results attached) }\end{array}$ & 0.04 & 0.11 \\
\hline
\end{tabular}

* significant at $p<0.05$. Share in the tourism market (TM), Schneider's index (SI), Charvat's index (CHI), tourism density (TD), number of economic enterprises (providing accommodation and food services) for every $10 \mathrm{~km}^{2}$ (NEEA), Coefficient of determination $\left(R^{2}\right)$, $F$ test statistic $(F)$.

The analysis shows a positive correlation between the protected areas size and variables TM, SI, CHI, and TD, and the level of tourism competitiveness of the region. The value of the Pearson correlation coefficient points to the significant correlation for variable TM and the region's competitiveness, whereas for the other variables it is a low correlation. As for the woodland area, there are no significant correlation values for each pair of variables. The size of the parks and green areas are only positively correlated with variable NEEA, which refers to the number of tourism enterprises. In that case, however, one must consider the correlation value low.

The interdependencies were confirmed by regression functions. Table 6 presents only significant results. In all the cases, the linear functions (for variables TM, SI, CHI, TD, and NEEA) showed a positive slope, similarly to the coefficients of correlation. However, the overlap of the estimated theoretical models with the empirical data was poor, which is seen from a low result of $R^{2}$. A maximum $23 \%$ of the changes in the dependent variable were accounted for with the changes resulting from the size of the protected areas. For that reason, around $80 \%$ of the changes in all the cases were due to other reasons. For the analysis of the dependencies between the level of competitiveness of the region and the areas protected by law, a polynomial ordered logit model was applied; the detailed results are presented in Table A1. The estimates of the parameters facilitate determining the direction of the dependence between the qualitative dependent variable and the independent variable. The positive parameter of protected areas size means that the larger the size, the higher the level of the region's competitiveness. In addition, the model prediction potential must be considered good as the number of "correctly predicted" cases accounted for $77 \%$.

\subsection{Discussion}

The contemporary environment forces ongoing changes in the operation of market enterprises. Tourism competitiveness has become more intensive across the destinations, irrespective of whether they are cities, regions, or countries [48]. A flexible adaptation of the regions to the existing competitiveness conditions is becoming a necessity and it is conditioned by having natural and other various resources, and their skillful use. A positive effect of the qualities of outstanding natural beauty as an essential tourism competitiveness factor was also confirmed in other studies [13,25,49]. Attila, on the other hand, investigating localities in Hungary, found that the level of tourism development and competitiveness was positively correlated with the level of hotel sector development [33]. A tourism competitiveness 
enhancement for rural areas can be also related to the development of agritourism. The existing trends and the future of agritourism have been reported (e.g., Barbieri [36]). A detailed review of agritourism research was made by Bhatta and Ohe [50].

A considerable limitation to performing tourism competitiveness research is a lack of availability of detailed data at the adequate level of spatial aggregation. The limitations related to investigating the level of tourism competitiveness are reported by, e.g., Dominguez et al. [51] and Crouch [52].

One of essential limitations is also a lack of information on the number of tourists visiting a given region as the so-called 'one-day visitors' not using any accommodation. Another problem in terms of the number of tourists and overnight stays is missing information on the accommodation available but not included in the statistics. In Poland, one of the cases of unrecorded businesses (e.g., an agritourism farm) is a possibility of offering up to five guest rooms. In such a case, a business is tax-exempt [53]. The limitations due to the inadequacy and inaccuracy of hiking statistics are also covered by Aroca et al. [54].

\section{Conclusions}

The analysis of rural areas tourism competitiveness suggests that the area of five provinces researched differs in terms of tourism competitiveness. Interestingly, the analysis of tourism competitiveness based on tourist-related data provides similar results as for the analysis of tourism competitiveness related to business entities. There is, however, a significant positive correlation between the size of areas of outstanding natural beauty and the level of the region's tourism competitiveness. The research hypothesis formulated in this paper is confirmed. The business-entities-related analysis showed a higher level of tourism competitiveness for the rural rather than urban-rural communes.

In the areas with lesser natural qualities, to get the tourists interested in a given region, one can compete with an innovative offer for tourists [55]. Such an offer can be proposed by, e.g., tourism organizations (creating a tourism product), the local authorities at the commune level, and tourist facilities (guest houses, agritourism farms) [56]. There is a high competitiveness among the agritourism farms [57]. In the area under study, there are conditions favorable to the development of innovative tourism-related forms [58]. Enhancing the competitiveness of the region through the innovativeness of such offers results from many factors, as presented in Figure 3.

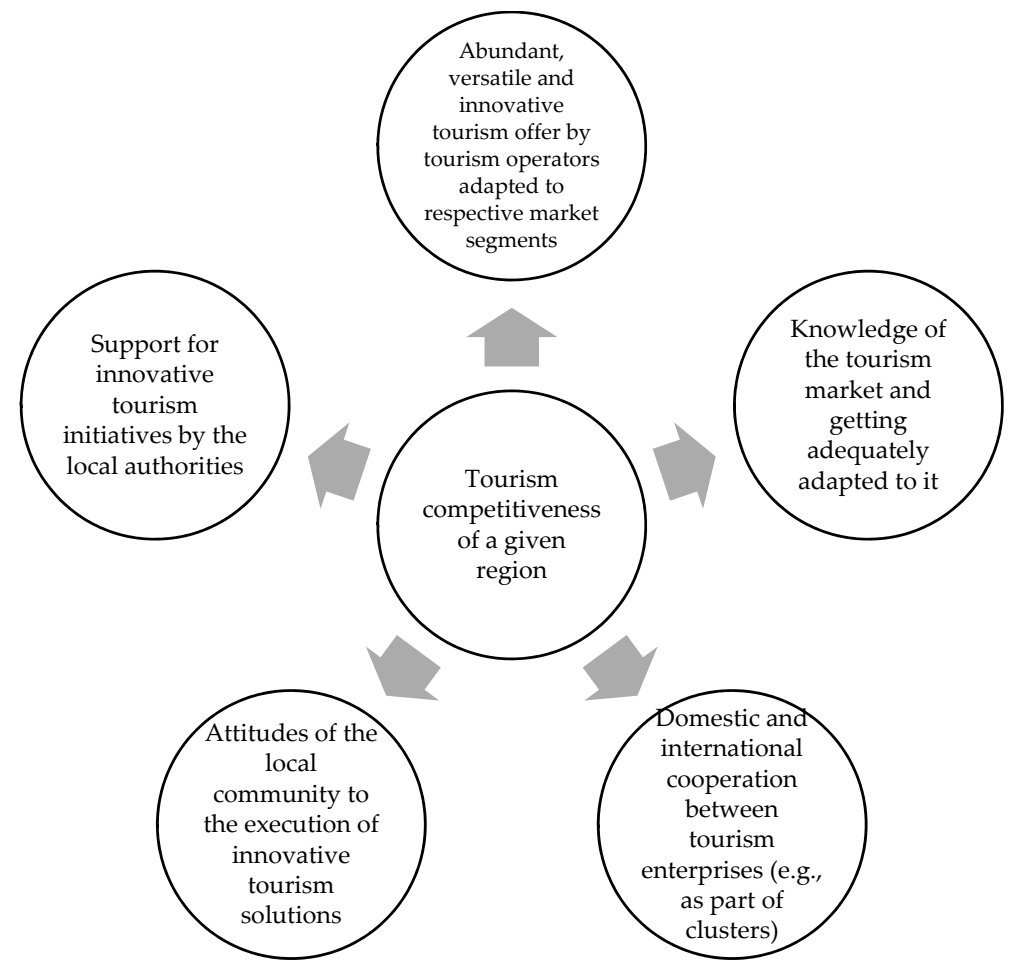

Figure 3. Factors enhancing the tourism competitiveness of the region under study. Source: [59-63]. 
These elements have a significant effect on enhancing the tourism competitiveness of the region analyzed. The idea and the sources of financing are very important [64]. However, the factors presented in Figure 3 should be interrelated to enhance the tourism competitiveness of the region. The owners of facilities for tourists should create a varied tourism offer for different market segments (e.g., the elderly, the disabled, parents with children, organized groups, single guests, and others) [65]. One must find a niche on the tourism services market for the idea to be executed. Additionally, cooperation with various tourism entities (e.g., with other owners of facilities for tourists at home and abroad, with the local authorities at the commune level, with the local community, and with tourists) is essential [66]. Frequently innovative tourism ideas are created in cooperation with the rural residents (e.g., theme villages and tourism clusters) [67].

Tourism innovativeness is an essential factor for a region's tourism competitiveness. Applying innovations can enhance the possibilities of adapting the tourist activity and the product offer to changing trends in the tourism demand and in the market environment [68]. It can have an effect on winning a more competitive position. At the same time, it must be stressed that an important aspect of innovation is its social utility, and thus improved satisfying of the needs and expectations of today's tourists and accomplishing an enhanced tourism business effectiveness [69]. Introducing innovative solutions is possible by creating, from scratch, an original tourism product and a professional marketing environment for the specific area's natural and cultural assets [27].

A development of tourism in rural areas can be an essential factor for the economic recovery of many regions, both in Poland and other countries. As in every economic sector, also here there is a high competition across regions. The research results presented can be useful and practical to various stakeholders directly or indirectly related to the tourism sector in rural areas (local authorities, consulting institutions, trade associations, lobbyists, entrepreneurs offering tourism and recreation, and food services) for analyzing the factors conditioning the tourism attractiveness of a given region to provide the grounds for integrated actions for a joint and holistic sector development strategy. Further research is planned to incorporate the countries of the European Union.

Author Contributions: Conceptualization, M.R. (Michał Roman), M.R. (Monika Roman), P.P., and M.S.; data curation, M.R. (Monika Roman) and M.R. (Michał Roman); formal analysis, M.R. (Michał Roman) and M.R. (Monika Roman); methodology, M.R. (Monika Roman) and M.R. (Michał Roman); resources, M.R. (Michał Roman) and M.R. (Monika Roman); visualization, M.R. (Michał Roman) and M.R. (Monika Roman); writing-original draft, M.R. (Monika Roman), M.R. (Michał Roman), and P.P.; writing-review and editing, M.R. (Michał Roman), M.R. (Monika Roman), and P.P.; supervision, M.R. (Michał Roman), M.R. (Monika Roman), P.P., and M.S.; funding acquisition, P.P. and M.S. All authors have read and agreed to the published version of the manuscript.

Funding: This research received no external funding.

Conflicts of Interest: The authors declare no conflict of interest.

\section{Appendix A}

Table A1. Selected logit model results.

\begin{tabular}{cccc}
\hline Specification & Coefficient & Std. Error & $\mathbf{z}$ \\
\cline { 2 - 4 } Protected areas size & $4.352 *$ & 1.199 & 3.630 \\
cut1 & $3.316^{*}$ & 0.699 & 4.745 \\
cut2 & $4.819 *$ & 0.852 & 5.657 \\
cut3 & $6.118^{*}$ & 1.077 & 5.679 \\
Number of cases "correctly predicted" $=64(77.1 \%)$ \\
Likelihood ratio test: Chi ${ }^{2}=26.976(0.0000)$ \\
* significant at $p<$ 0.05. Coefficient of determination $\left(\mathrm{R}^{2}\right), \mathrm{Chi}^{2}$ test statistic $\left(\mathrm{Chi}^{2}\right)$, z-statistics (z).
\end{tabular}




\section{References}

1. Feurer, D.; Chaharbaghi, K. Defining Competitiveness: A Holistic Approach. Manag. Decis. 1994, 32, 49-58. [CrossRef]

2. Organisation for Economic Co-operation and Development. Technology and the Economy. The Key Relationships; Elsevier: Paris, France, 1992.

3. World Economic Forum. The Global Competitiveness Report; World Economic Forum: Geneva, Switzerland, 1994.

4. IMD World Competitiveness Center. The World Competitiveness Yearbook 1997; IMD World Competitiveness Center: Lausanne, Switzerland, 1997.

5. Plummer, P.; Tonts, M.; Martinus, K. Endogenous growth, local competitiveness and regional development: Western Australia's Regional Cities, 2001-2011. J. Econ. Soc. Policy 2014, 16, 146-176.

6. Boschma, R. Competitiveness of Regions from an Evolutionary Perspective. Reg. Stud. 2004, 38, 1001-1014. [CrossRef]

7. Popkova, E.; Gornostaeva, Z.; Tregulova, N. Role of innovations in provision of competitiveness and innovational development of economy and overcoming of "underdevelopment whirlpools" in Russia and countries of Eastern Europe. J. Entrep. Emerg. Econ. 2018, 10, 511-523. [CrossRef]

8. Zhang, H.; Geng, Z.; Yin, R.; Zhang, W. Regional differences and convergence tendency of green development competitiveness in China. J. Clean. Prod. 2020, 254, 119922. [CrossRef]

9. Enright, M.J.; Newton, J. Tourism destination competitiveness: A quantitative approach. Tour. Manag. 2004, 25, 777-788. [CrossRef]

10. Kozak, M.; Rimmington, M. Measuring tourist destination competitiveness: Conceptual considerations and empirical findings. International. J. Hosp. Manag. 1999, 18, 273-283. [CrossRef]

11. Delgado, M.; Ketels, C.; Porter, M.E.; Stern, S. The Determinants of National Competitiveness. Natl. Bur. Econ. Res. 2012, 18249, 1-47.

12. Cracolici, M.F.; Nijkamp, P. The attractiveness and competitiveness of tourist destinations: A study of Southern Italian regions. Tour. Manag. 2009, 30, 336-344. [CrossRef]

13. Kułyk, P.; Brelik, A. Tourist Competitiveness of Polish Rural Areas. Eur. Res. Stud. J. 2019, 4, 379-387. [CrossRef]

14. Carmichael, B.A.; Senese, D.M. Competitiveness and Sustainability in Wine Tourism Regions: The Application of a Stage Model of Destination Development to Two Canadian Wine Regions. In The Geography of Wine; Dougherty, P., Ed.; Springer: Dordrecht, The Netherlands, 2011; pp. 159-178. [CrossRef]

15. Benito, B.; Solana, J.; Lopez, P. Determinants of Spanish Regions' Tourism Performance: A Two-Stage, Double-Bootstrap Data Envelopment Analysis. Tour. Econ. 2014, 20, 987-1012. [CrossRef]

16. Roman, M.; Roman, M.; Niedziółka, A. Spatial Diversity of Tourism in the Countries of the European Union. Sustainability 2020, 12, 2713. [CrossRef]

17. Dwyer, L.; Forsyth, P.; Rao, P. Price competitiveness of tourism packages to Australia: Beyond the "Big Mac" index. Asia Pac. J. Tour. Res. 2000, 5, 50-56. [CrossRef]

18. Dwyer, L.; Kim, C. Destination competitiveness and bilateral tourism flows between Australia and Korea. J. Tour. Stud. 2003, 14, 55-67.

19. Hudson, S.; Ritchie, B.; Timur, S. Measuring destination competitiveness: An empirical study of Canadian ski resorts. Tour. Hosp. Plan. Dev. 2004, 1, 79-94. [CrossRef]

20. Cheng, W.; Li, Z.; Jian, W. Discussions on the Core Competitiveness of Tourism Industry. Hum. Geogr. 2005, 1,1-16. Available online: http://en.cnki.com.cn/Article_en/CJFDTotal-RWDL200501012.htm (accessed on 10 September 2020).

21. Gomezelj, D.O.; Mihalič, T. Destination competitiveness-Applying different models, the case of Slovenia. Tour. Manag. 2008, 29, 294-307. [CrossRef]

22. Navickas, V.; Malakauskaite, A. The Possibilities for the Identification and Evaluation of Tourism Sector Competitiveness Factors. Eng. Econ. 2009, 61, 37-44.

23. Malakauskaite, A.; Navickas, V. The Role of Clusters in the Formation Process of Tourism Sector Competitiveness: Conceptual Novelties. Econ. Manag. 2010, 15, 149-154.

24. Sánchez, C.I.; Jaramillo-Hurtado, M.E. Policies for enhancing sustainability and competitiveness in tourism in Colombia. Worldw. Hosp. Tour. Themes 2010, 2, 153-162. [CrossRef] 
25. Angelkova, T.; Koteski, C.; Jakovlev, Z.; Mitrevska, E. Sustainability and Competitiveness of Tourism. Procedia Soc. Behav. Sci. 2012, 44, 221-227. [CrossRef]

26. Dupeyras, A.; MacCallum, N. Indicators for Measuring Competitiveness in Tourism: A Guidance Document; OECD Tourism Papers, 2013/02; OECD Publishing: Paris, France, 2013. [CrossRef]

27. Mazurek, M. Competitiveness in Tourism-Models of Tourism Competitiveness and Their Applicability: Case study Austria and Switzerland. Eur. J. Tour. Hosp. Recreat. 2014, Special Issue, 73-94.

28. Santos, M.C.; Ferreira, A.M.; Costa, C. Influential factors in the competitiveness of mature tourism destinations. Tour. Manag. Stud. 2014, 10, 73-81.

29. Webster, C.; Ivanov, S. Transforming competitiveness into economic benefits: Does tourism stimulate economic growth in more competitive destinations? Tour. Manag. 2014, 40, 137-140. [CrossRef]

30. Krstić, B.; Jovanovic, S.; Stanisic, T. Central and East European Countries Tourism Competitiveness as a Factor of Their National Competitiveness Level. Rev. Tur. Stud. Cercet. Tur. 2014, 18, 61-68.

31. Knežević Cvelbar, L.; Dwyer, L.; Koman, M.; Mihalič, T. Drivers of Destination Competitiveness in Tourism: A Global Investigation. J. Travel Res. 2015, 55, 1041-1050. [CrossRef]

32. Mastronardi, L.; Giaccio, V.; Giannelli, A.; Scardera, A. Is agritourism eco-friendly? A comparison between agritourisms and other farms in Italy using farm accountancy data network dataset. SpringerPlus 2015, 4, 1-12. [CrossRef]

33. Attila, A.T. The Impact of the Hotel Industry on the Competitiveness of Tourism Destinations in Hungry. J. Compet. 2016, 8, 85-104.

34. Andrades, L.; Dimanche, F. Destination competitiveness and tourism development in Russia: Issues and challenges. Tour. Manag. 2017, 62, 360-376. [CrossRef]

35. Liu, S.Y.; Yen, C.Y.; Tsai, K.N.; Lo, W.S. A Conceptual Framework for Agri-Food Tourism as an Eco-Innovation Strategy in Small Farms. Sustainability 2017, 9, 1683. [CrossRef]

36. Barbieri, C. Agritourism research: A perspective article. Tour. Rev. 2019, 75, 149-152. [CrossRef]

37. Fotiadis, A.; Nuryyev, G.; Achyldurdyyeva, J.; Spyridou, A. The Impact of EU Sponsorship, Size, and Geographic. Sustainability 2019, 11, 2375. [CrossRef]

38. Murtagh, F. Ward's Hierarchical Agglomerative Clustering Method: Which Algorithms Implement Ward's Criterion? J. Classif. 2014, 31, 274-295. [CrossRef]

39. Ward, J.H. Hierarchical Grouping to Optimize an Objective Function. J. Am. Stat. Assoc. 1963, 58, $236-244$. [CrossRef]

40. Sarle, W.S. Cubic Clustering Criterion; Technical Report A-108; SAS Institute Inc.: Cary, NC, USA, 1983.

41. Calinski, T.; Harabasz, J.A. Dendrite Method for Cluster Analysis. Commun. Stat. Theory Method. 1974, 3, 1-27. [CrossRef]

42. Statistics Poland. Tourism Statistics. Available online: https://bdl.stat.gov.pl/BDL/dane/podgrup/temat (accessed on 1 August 2020).

43. Żegań, P.; Stec, M.; Berwińska-Małajowicz, A. Tourist Function Development in EU Countries. Acta Tur. 2019, 31, 115-151.

44. Szromek, A.R. Pomiar funkcji turystycznej obszarów za pomocą wskaźników funkcji turystycznej na przykładzie obszarów państw europejskich (The Measurement of Tourism Function of Areas Using Indicators of the Tourism Function on the Example of Areas of European Countries). Studia Ekon. 2013, 132, 91-103.

45. Grabowski, J. Uwarunkowania konkurencyjności turystycznej regionów (Conditions for Effective Competition Among Tourist Regions). Ruch Praw. Ekon. I Socjol. 2008, 3, 149-164.

46. Hendel, M. Przydatność wskaźników funkcji turystycznej w ocenie rozwoju turystycznego obszaru na przykładzie gminy Utroń (Applicability of Tourist Function Indexes in Evaluation of Tourism Area Development on the Example of Ustron Commune). Zesz. Nauk. Politech. Ślaskiej. Ser. Organ. I Zarzadzanie 2016, 87, 157-170.

47. Szromek, A. Wskaźniki funkcji turystycznej i ich współzależność z innymi wskaźnikami ekonomicznymi na przykładzie polskiej gospodarki w latach 2000-2010 (Indicators of Tourist Function and their Correlation with Other Economic Indicators on the Example of Polish Economy in 2000-2010). Pr. Nauk. Uniw. Ekon. We Wroctawiu 2013, 304, 325-338.

48. Barbosa, L.G.M.; De Oliveira, C.T.F.; Rezende, C. Competitiveness of Tourist Destinations: The Study of 65 Key Destinations for the Development of regional Tourism. Rev. De Adm. Públicia 2010, 44, 1067-1095. [CrossRef] 
49. Crouch, G.I.; Ritchie, J.R.B. Tourism, competitiveness, and social prosperity. J. Bus. Res. 1999, 44, 137-152. [CrossRef]

50. Bhatta, K.; Ohe, Y. A Review of Quantitative Studies in Agritourism: The Implications for Developing Countries. Tour. Hosp. 2020, 1, 23-40. [CrossRef]

51. Dominguez, T.; Darcy, S.; Alen, E. Competing for the disability tourism market-A comparative exploration of the factors of accessible tourism competitiveness in Spain and Australia. Tour. Manag. 2015, 47, 261-272. [CrossRef]

52. Crouch, G.I. Destination competitiveness: An analysis of determinant attributes. J. Travel Res. 2011, 50, $27-45$. [CrossRef]

53. Kubal, M.; Mika, M. Agritourism in Poland-The Legal Model and the Realities of the Market. Curr. Issues Tour. Res. 2012, 2, 4-11.

54. Aroca, P.; Brida, J.G.; Volo, S. Tourism statistics: Correcting data inadequacy. Tour. Econ. 2016, $23,99-112$. [CrossRef]

55. Simonceska, L. The changes and innovation as a factor of competitiveness of the tourist offer (the case of Ohrid). Procedia Soc. Behav. Sci. 2012, 44, 32-43. [CrossRef]

56. Ghimire, K.B. Regional tourism and South-South economic cooperation. Geogr. J. 2001, 167, 99-110. [CrossRef]

57. Campon-Cerro, A.M.; Hernandez-Mogollon, J.M.; Alves, H. Sustainable improvement of competitiveness in rural tourism destinations: The quest for tourist loyalty in Spain. J. Destin. Mark. Manag. 2017, 6, 252-266. [CrossRef]

58. Tescașiu, B.; Epuran, G.; Tecău, A.S.; Chițu, I.B.; Mekinc, J. Innovative Forms of Economy and Sustainable Urban Development-Sharing Tourism. Sustainability 2018, 10, 3919. [CrossRef]

59. Czernek, K. Determinants of Cooperation a Tourist Region. Ann. Tour. Res. 2013, 40, 83-104. [CrossRef]

60. Sigurðardóttir, I.; Steinthorsson, R.S. Development of micro-clusters in tourism: A case of equestrian tourism in northwest Iceland. Scand. J. Hosp. Tour. 2018, 18, 261-277. [CrossRef]

61. Blackstock, K. A critical look at community based tourism. Community Dev. J. 2005, 40, 39-49. [CrossRef]

62. Dolnicar, S. Market segmentation in tourism. In Tourism Management, Analysis, Behaviour and Strategy; Woodside, A., Martin, D., Eds.; CABI: Cambridge, UK, 2008.

63. Holder, J.S. The need for public-private sector cooperation in tourism. Tour. Manag. 1992, 13, 157-162. [CrossRef]

64. Bodlender, J.A. The financing of tourism projects. Tour. Manag. 1982, 3, 277-284. [CrossRef]

65. Moutinho, L. Consumer Behaviour in Tourism. Eur. J. Mark. 1987, 21, 5-44. [CrossRef]

66. Teye, V.B. Prospects for regional tourism cooperation in Africa. Tour. Manag. 1988, 9, 221-234. [CrossRef]

67. Kim, B.K.; Son, H.G.; Lee, M.S.; Park, I.H. The Effect of Rural Tourism Village Visitors' Selection Attributes toward Satisfaction and Revisit Intention. J. Agric. Ext. Community Dev. 2011, 18, 531-550.

68. Kallmuenzer, A.; Peters, M. Innovativeness and control mechanisms in tourism and hospitality family firms: A comparative study. Int. J. Hosp. Manag. 2018, 70, 66-74. [CrossRef]

69. Pechlaner, H.; Smeral, E.; Matzier, K. Customer value management as a determinant of the competitive position of tourism destinations. Tour. Rev. 2002, 57, 15-22. [CrossRef]

Publisher's Note: MDPI stays neutral with regard to jurisdictional claims in published maps and institutional affiliations.

(C) 2020 by the authors. Licensee MDPI, Basel, Switzerland. This article is an open access article distributed under the terms and conditions of the Creative Commons Attribution (CC BY) license (http://creativecommons.org/licenses/by/4.0/). 